\title{
Contributions to the study of the genus Reptalus Emeljanov, 1971 (Homoptera: Auchenorrhyncha: Cixiidae) of Western Tien Shan Mountains
}

\section{К изучению видов рода Reptalus Emeljanov, 1971 (Homoptera: Auchenorrhyncha: Cixiidae) Западного Тянь-Шаня}

\author{
A.F. Emeljanov ${ }^{1}$, D.Yu. Tishechkin ${ }^{2}$ \\ А.Ф. Емельянов ${ }^{1}$, А.Ю. Тишечкин ${ }^{2}$
}

\footnotetext{
${ }^{1}$ Zoological Institute, Russian Academy of Sciences, Universitetskaya nab., 1, St. Petersburg 199034, Russia. E-mail: hemipt@zin.ru

1 Зоологический институт РАН, Университетская наб., 1, С.-Петербург 199034, Россия.

2 Department of Entomology, Faculty of Biology, M.V. Lomonosov Moscow State University, Vorobyevy Gory, Moscow 119991, Russia. E-mail: macropsis@yandex.ru

2 Кафедра энтомологии Биологического факультета Московского государственного университета имени М.В. Ломоносова, Воробьёвы Горы, Москва 119991, Россия.
}

KEY WORDS: Auchenorrhyncha, Cixiidae, Reptalus, taxonomy, variability, vibrational signals, Central Asia, Tien Shan Mts.

КЛЮЧЕВЫЕ СЛОВА: Auchenorrhyncha, Cixiidae, Reptalus, систематика, изменчивость, вибрационные сигналы, Средняя Азия, Тянь-Шань.

ABSTRACT. Data on morphological variability of Reptalus nigrovenosus (Kusn.) are presented, $R$. narynensis Emeljanov et Tishetshkin sp.n. closely related to the previous species is described. Both species produce calling signals with very similar temporal pattern and dwell on the same altitude in similar biotopes. On the other hand, they were never found in the same locality. Possibly, this is the similarity of signal structure that is the reason for their vicariation.

РЕЗЮМЕ. Приведены данные по морфологической изменчивости Reptalus nigrovenosus, описан близкий к нему $R$. narynensis Emeljanov et Tishetshkin sp.n. Оба вида издают призывные сигналы с чрезвычайно сходным временным рисунком и встречаются в одном и том же высотном поясе в сходных биотопах. В то же время, оба вида ни разу не были обнаружены в одном местонахождении. Возможно, причиной подобного викарирования является именно сходство структуры их звуковых сигналов.

The family Cixiidae (Homoptera: Auchenorrhyncha) in Central Asia has been the objective of much research. Up to now, it is not sufficiently studied in this region, however. Suffice it to say that in the recent list of Auchenorrhyncha of Kyrgyzstan 11 species of Cixiidae are recorded, 9 of which remained unidentified [Novikov et al., 2006]. In the present paper we provide a new data on morphology, taxonomy and biology of the representatives of the genus Reptalus Emeljanov, 1971 from Western Tien Shan Mts.

The material investigated is deposited in the collections of the Zoological Institute of the Russian Academy of Sciences, St. Petersburg (ZIN) and of the Zoological Museum of M.V. Lomonosov Moscow State University (ZMMU).

\section{Reptalus nigrovenosus (Kusnezov, 1937)}

MATERIAL INVESTIGATED: Kyrgyzstan, W Tien-Shan Mts., Chatkal'skiy Mtn. Ridge, Sary-Chelekskiy Nature Reserve, Arkyt Village, on bushes in dry gorge, about $1200 \mathrm{~m}$ above sea level, 18.VII. 2008 (D.Yu. Tishechkin), $2 \sigma^{7} \sigma^{7}$, recordings of calling signals of $1 \mathrm{O}^{\text {t }}$ are made at $23-24{ }^{\circ} \mathrm{C}$ (ZIN, ZMMU); same locality and biotope, 3.VII.2009 (D.Yu. Tishechkin), $1 \mathrm{O}^{\text {, }}$, recordings of calling signals are made at $20-21{ }^{\circ} \mathrm{C}(\mathrm{ZIN})$.

Several males collected in the buffer zone of Sary-Cheleksky Nature Reserve (eastern part of Chatkal'sky Mtn. Ridge) differ from the specimens from other regions of Tien Shan Mts. in certain characters. This form may prove to be a new subspecies, but the material available is insufficient for its segregation. For this reason presently we give a description of this form in aim to provide new data on morphological variability of this species.

Coryphe is somewhat more narrow than in typical $R$. nigrovenosus, slightly narrowed towards the apex, with hind margin more or less rectangularly cut. Fore margin produced forward at a sharp angle close to right one, apex rounded. Acrometope short, with straight fore (intermetopal) keel, in the middle with two longitudinal short keels situated close to each other and forming more or less square area with slightly concave small cell. Bifurcation of the middle keel of eumetope small, sharp-angled, occupies one-third of the metope width in this place.

Head black with light brown keels. Side margins of eumetope more light, whitish, light areas are wider than the keels. At the lower end of clypeus light areas are extended towards the midline in a wedge-shape. Pronotum widely lightened along the keels, disk and paradiskal fields are entirely light; there are only two small dark spots on both sides of the median keel. 
Supraocular area as well as the area between postocular keel and light-coloured hind margin are brown. Paranotal lobes black with light margins. Scutellum black. Tegulae brown with light margins. Fore wings semitransparent with slight milkywhite tinge, veins light brown, almost white. Granules bearing setae are black on $C$ along the hind margin and on $R$ within corium, but are indistinct and not darkened on other longitudinal veins; setae rather long and thin. Transverse veins darkened, with dark speckles in basal part of a membrane and entirely black in its distal part. Ramification of clavus and fore branch of $\mathrm{Cu}$ with dark diffuse spots, hind margin of pterostigma with brown stripe. Sclerotized parts of undersurface of notum are black, membranous parts (i.e. metanotum before coxae) light brown. Coxae and femora dark brown to black,

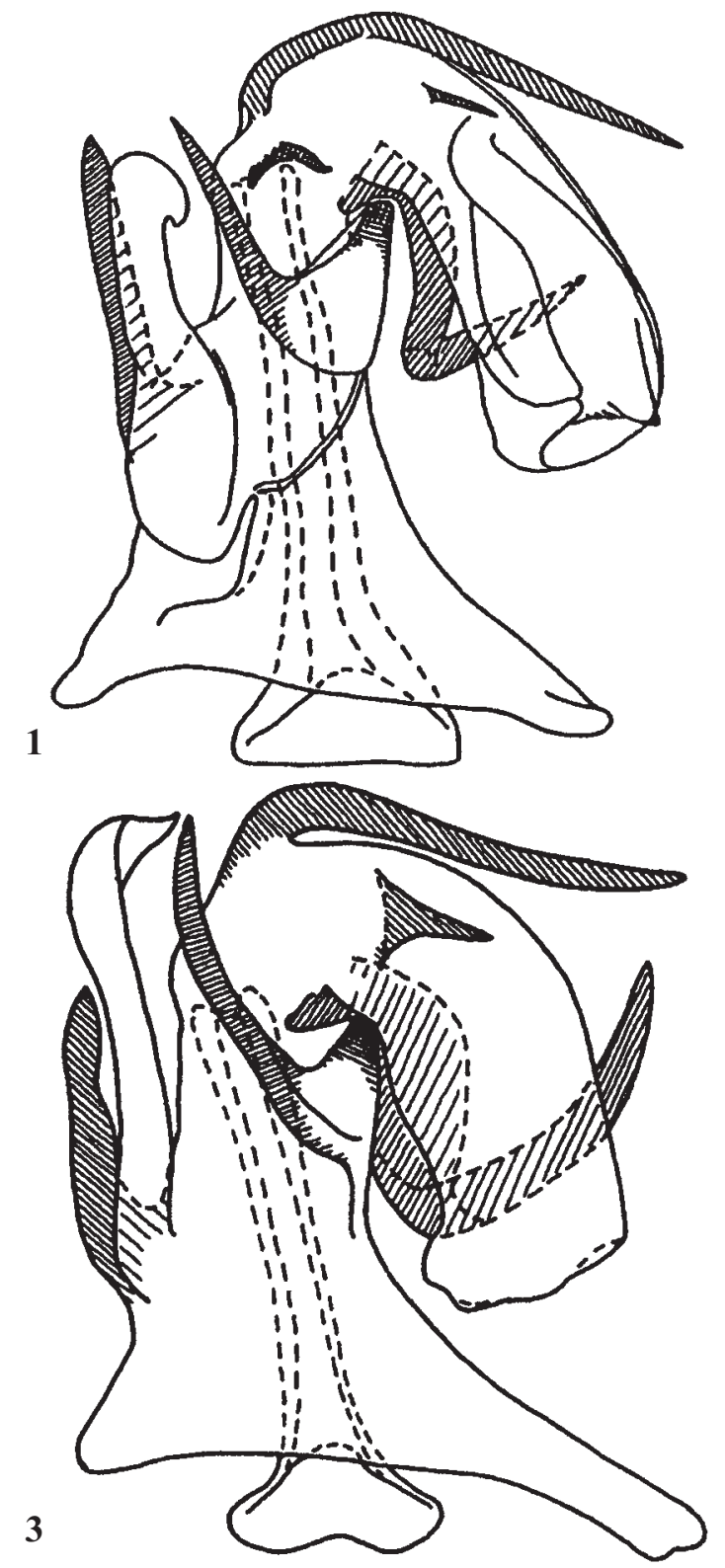

tibiae brown, dorsal sides of hind tibiae are whitish. Underside of abdomen dark brown with light hind margins of segments. Pygofer in male dark brown, styles brown to dark brown, anal tube broadly lightened on side and hind margins.

In typical form, penis with two parallel appendages on the right side of theca (phallobasa), one being straight, another with a hook-like tip (Figs 1-2). These two appendages correspond in their position to the right paramere; left basal appendage (paramere) is absent. Apical part of theca with large appendage bent caudad. Distal article of penis with three appendages, ventrobasal (S-shaped), basal in caudal part, and a small subbasal appendage on dorsal side.

Specimens from Sary-Cheleksky Nature Reserve differ from typical form in the shape of penis appendages. In typical

Figs 1-4. Penis of Reptalus nigrovenosus (Kusn.): 1, 3- dorsal view; 2, 4 - ventral view; 1-2 - specimen from Mogoltau Mts., NW of Khudzhand, Sughd Province, Tadzhikistan; 3-4 - specimen from Sary-Cheleksky Nature Reserve, Kyrgyzstan.

Рис. 1-4. Пенис Reptalus nigrovenosus (Kusn.): 1, 3 - сверху; 2, 4- снизу; 1-2 - экземпляр с хребта Моголтау к С3 от Худжанда, Согдийская обл., Таджикистан; 3-4 - экземпляр из Сары-Челекского заповедника, Кыргызстан. 
form straight and hook-shaped appendages at the base of penis (i.e. appendages of right paramere) are of approximately the same length, whereas in the specimens from SaryCheleksky Reserve straight appendage is shorter than hookshaped one (Figs 3-4). S-shaped ventral and small subbasal dorsal appendages of a distal article in the form from SaryCheleksky Reserve are larger than in typical one.

Pygopher, anal tube and styles in the specimens from different localities are indistinguishable (Figs 5-12).

Body length $4.7-5.7 \mathrm{~mm}$ in males, $5.5-6.5 \mathrm{~mm}$ in females.

Male calling signals are single echemes lasting for about $3.5-5 \mathrm{~s}$. Each echeme consists of short simple syllables, following each other with a period of $130-170 \mathrm{~ms}$ and including 6-10 pulses each (Figs 23-24, 26-27). Occasionally single additional pulses are present in the gaps between syllables (Fig. 26).
Reptalus narynensis Emeljanov et Tishetshkin sp.n.

MATERIAL. Holotype, $\sigma^{7}$ : Kyrgyzstan, Naryn Valley $20 \mathrm{~km}$ NNE of Tash-Kumyr, slopes with desert vegetation, 26.VII.1986 (A.F. Emeljanov)(ZIN). Paratypes: $10^{7}, 3$ of, same data (A.F. Emeljanov, M.G. Volkovitsh) (ZIN); $10^{7}$, Kyrgyzstan, ca. $20 \mathrm{~km} \mathrm{~N}$ of Tash-Kumyr, Tegene Pass, about $1200 \mathrm{~m}$ above sea level, 4.VII.2011 (D.Yu. Tishechkin); male vibrational calling signals were recorded at the temperature $21-22{ }^{\circ} \mathrm{C}$ (ZMMU).

DESCRIPTION. Coryphe slightly narrows towards the apex, somewhat wider than in $R$. nigrovenosus. Its hind margin with almost right- or obtuse-angled notch, fore margin produced forward, right- or slightly sharp-angled, apex blunt as if cut by the middle cell of acrometope. Acrometope short, with straight fore (intermetopal) keel and two short longitudinal keels merging together and forming the sides of

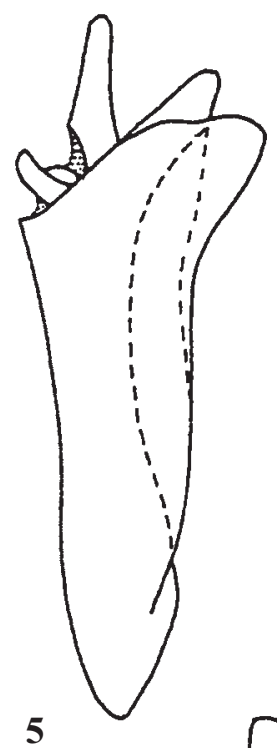

6

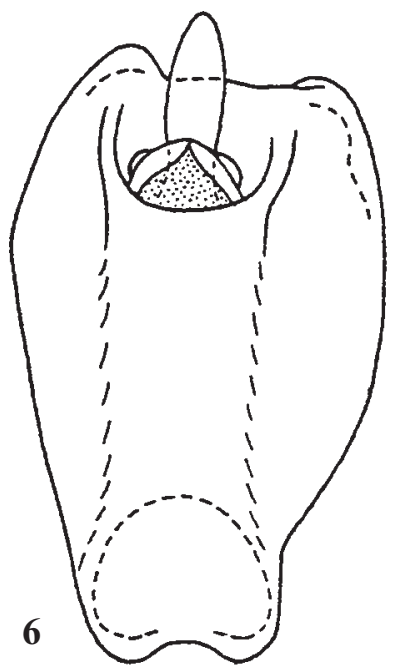

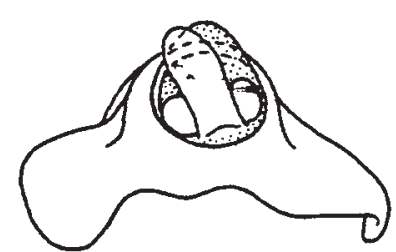

7

8

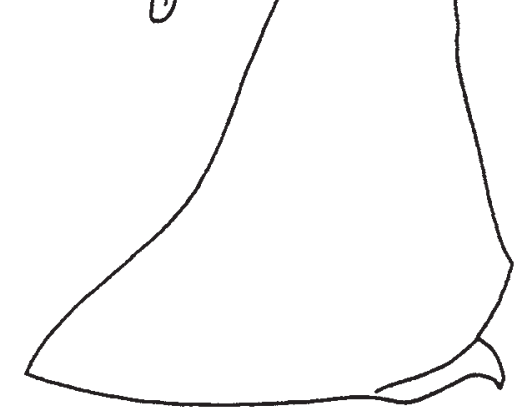

10
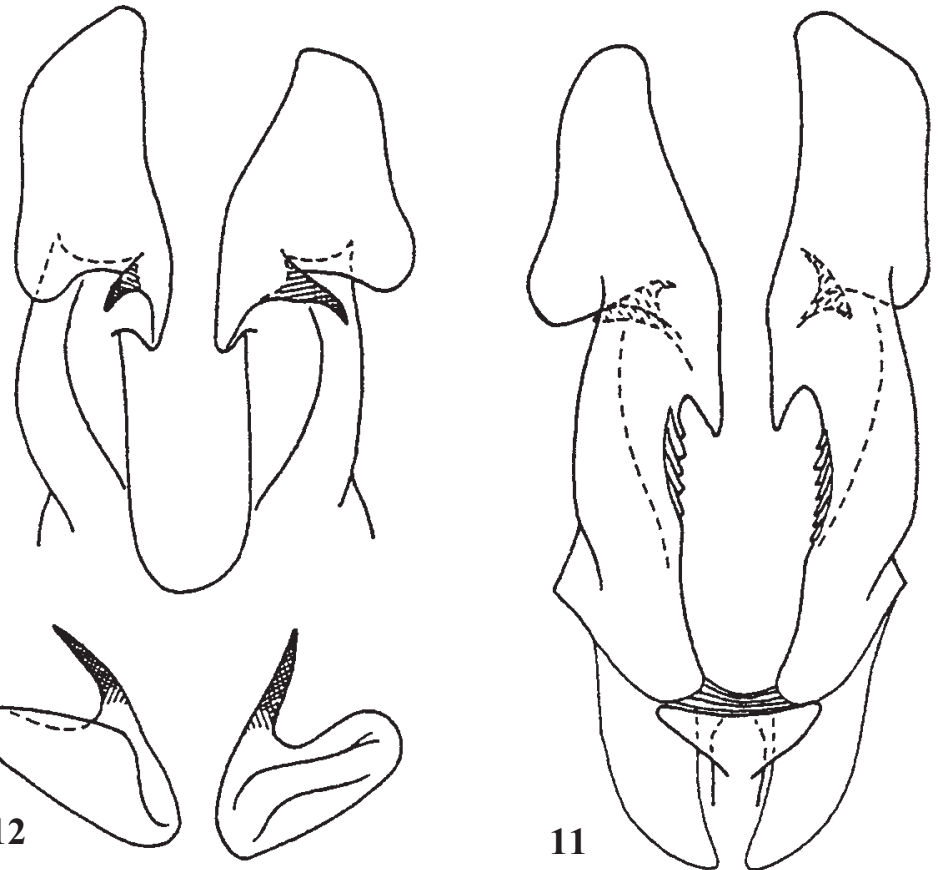

Figs 5-12. Male genitalia of Reptalus nigrovenosus (Kusn.): 5-7 — anal tube; 8 - pygofer; 9-12 - styles; 5, 8-9 - left side view; 6,10 - dorsal view; 7,12 - caudal view; 11 - ventral view.

Рис. 5-12. Гениталии самца Reptalus nigrovenosus (Kusn.): 5-7 — анальная трубка; 8 — пигофор; 9-12 — стилусы; 5, 8-9 слева; 6, 10 - сверху; 7, 12 - сзади; 11 - снизу. 
a median cell (in $R$. nigrovenosus these keels for the most part are totally merged and form the single keel). Furca of the middle keel of eumetope occupies one-third or somewhat more of intermetopal keel across the width.

Head black or dark brown with reddish brown or light brown keels. Side margins of eumetope lighter than other keels, light areas along the margins slightly broaden towards the clypeus. Epiclypeal lobes are almost entirely light. Middle keel of clypeus weakly lightened, sometimes is light only in the upper part adjacent to metope. Dorsal side of pronotum widely lightened, areas between the keels brownish or as light as the

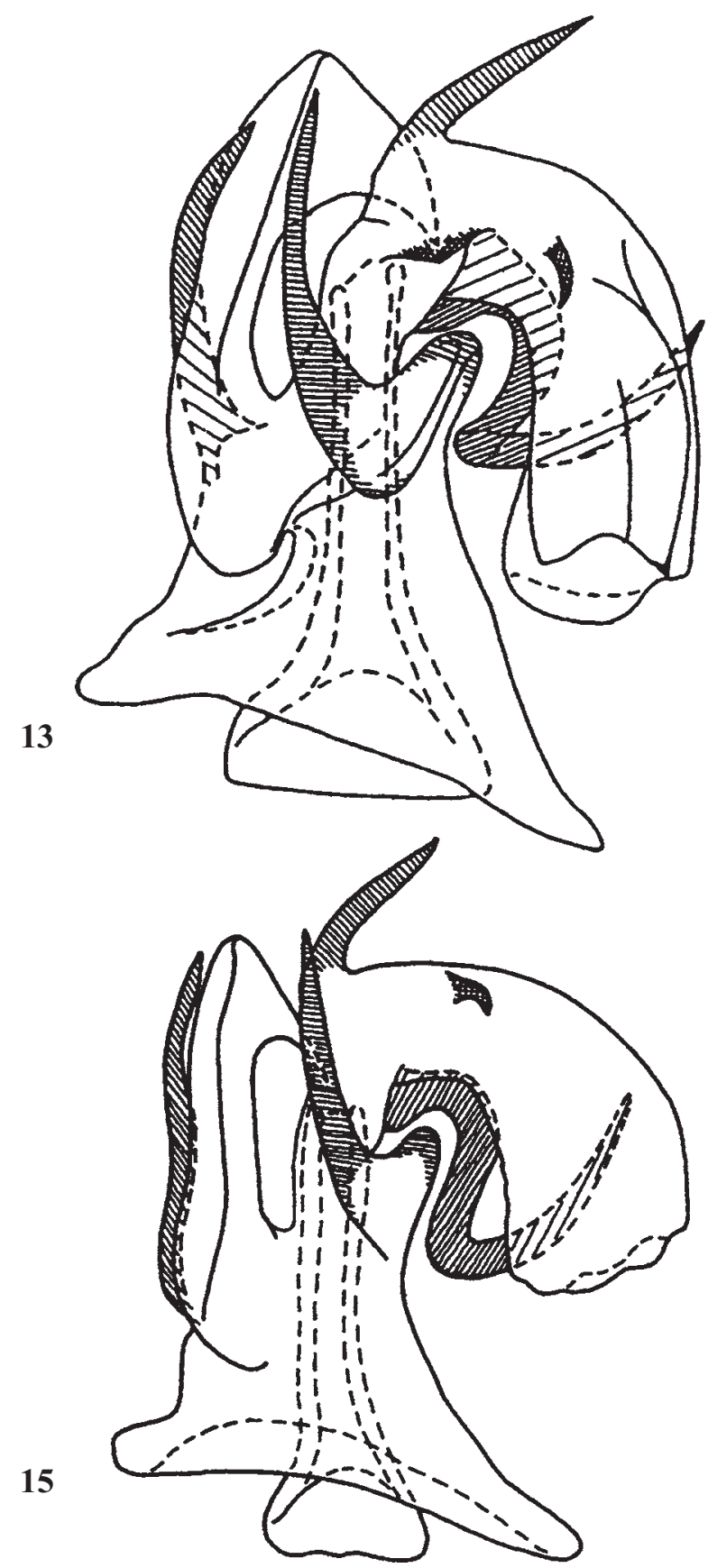

keels. Supraocular areas are almost covered by the hind margins of eyes, black, their upper margins are visible in front of postocular keel of pronotum. Paranotal lobes are darkened between the keels either entirely or only inwards from the pectoral keel. The latter one always has the same coloration as the surrounding areas, i.e. more or less dark. The margins of paranotes light. Scutellum entirely black or dark brown with reddish tinge. Tegulae light brown or almost white, with more light margins if brownish. Fore wings whitish, semitransparent, veins for the most part are light with dark speckles, longitudinal veins of membrana are darker than other ones,

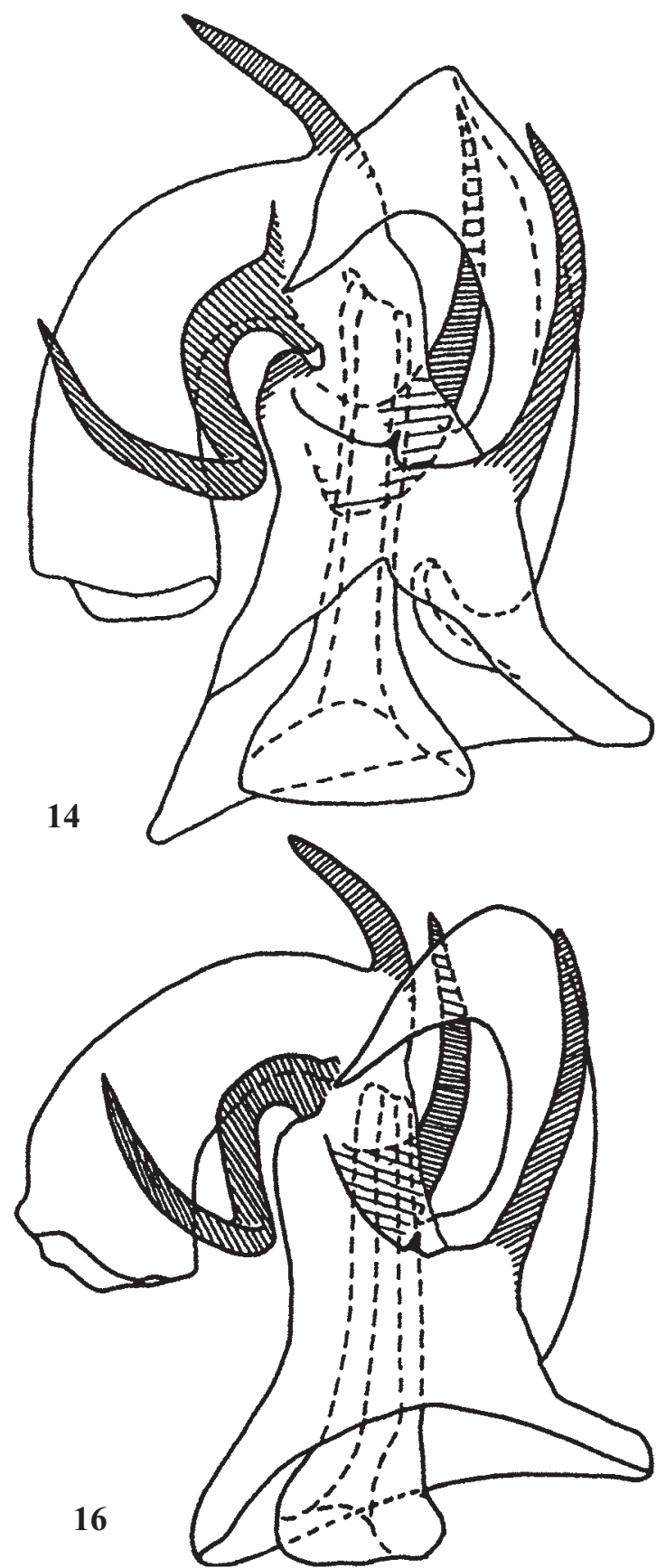

Figs 13-16. Penis of Reptalus narynensis sp.n.: 13, 15 - dorsal view; 14, 16 - ventral view; 13-14 - specimen from Naryn Valley; $15-16$ - specimen from Tegene Pass.

Рис. 13-16. Пенис Reptalus narynensis sp.n.: 13, 15 - сверху; 14, 16 - снизу; 13-14 - экземпляр из долины Нарына; 15-16экземпляр с перевала Тегене. 
transverse veins are bordered with dark stripes somewhat wider than the veins. In one female fore wings with weak brownish oblique stripes extending over the furca of clavus to the apical one-third of costal area. Granules on the fore wings with rather long slender hairs easy to break. Pterostigma is slightly darkened either entirely or only along the hind margin. Sclerotized parts of undersurface of notum are almost entirely dark, brown to black, with widely lightened hind margins. Coxae dark brown to black, femora brown to dark brown, their edges are of almost the same coloration as the main parts with the exception of more light fore-lower edge. Tibiae dark with light edges, fore tarsi brown, middle ones light brown, hind tarsi are almost white with black denticles. Male genitalia and female pygofer including ovipositor dark brown.

In the shape of penis and of other male genitalia structures is closely related to $R$. nigrovenosus (Figs 13-22). Most distinctly differs from the latter species in body length and in the shape and position of caudal appendage of distal article of penis. In the new species the appendage is shorter and directed caudad (Figs 13-16), whereas in $R$. nigrovenosus it is bent to the right, along the distal article (Figs 1-4).
Body length $4.5-5.0 \mathrm{~mm}$ in males, $5.0-5.3 \mathrm{~mm}$ in females. RANGE. Both localities are situated in the zone of mountain semideserts and steppes at the north-eastern boundary of Fergana Valley.

BIOLOGY. Specimens from Naryn Valley were collected on the slopes with sparse desert vegetation, the male from Tegene Pass was found on bushes in dry mountain steppes.

Male calling signals are similar to these of the previous species and are single echemes lasting for about 4-5 s. Each echeme consists of short syllables, including about 5-11 pulses each (Figs 25, 28-29). As in R. nigrovenosus, syllable repetition period averages $130-170 \mathrm{~ms}$, but not infrequently two or three syllables partially merge with each other to some extent (Fig. 29).

In many insect taxa temporal pattern of male acoustic signals is a crucial character for recognition of a conspecific mate. Differences in the signal structure provide one of the main precopulatory barriers of reproductive isolation between closely related species. For this reason coexistence of

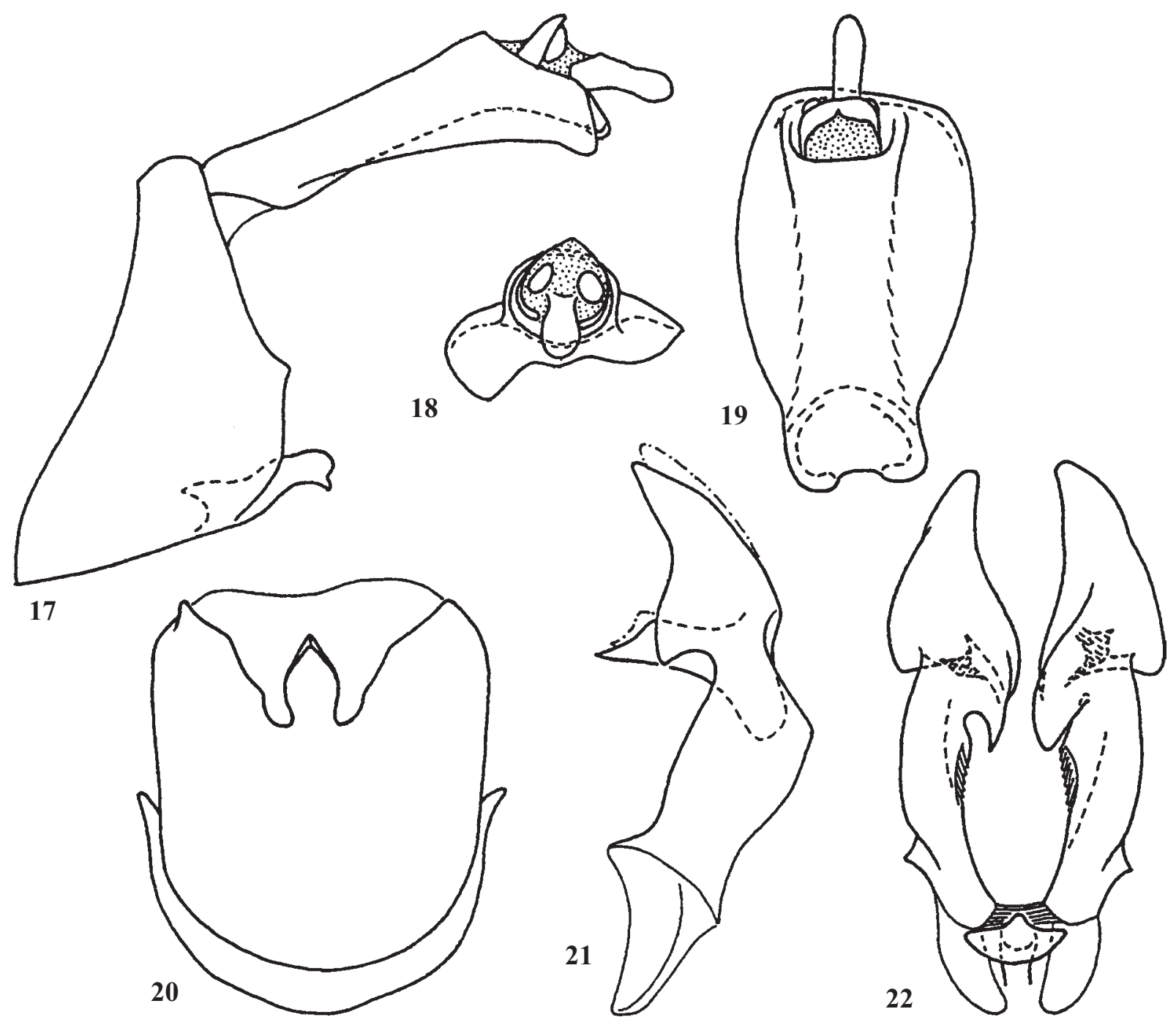

Figs 17-22. Male genitalia of Reptalus narynensis sp.n.: 17 - pygofer and anal tube; $18-19$ - anal tube; 20 - pygofer and sternite VIII; 21-22 - styles; 17, 21 - left side view; 18 - caudal view; 19 - dorsal view; 20, 22 - ventral view.

Рис. 17-22. Гениталии самца Reptalus narynensis sp.n.: 17 - пигофор и анальная трубка; 18-19 — анальная трубка; 20 пигофор и VIII стернит; 21-22 - стилусы; 17, 21 - слева; 18 - сзади; 19 - сверху; 20, 22 - снизу. 
23

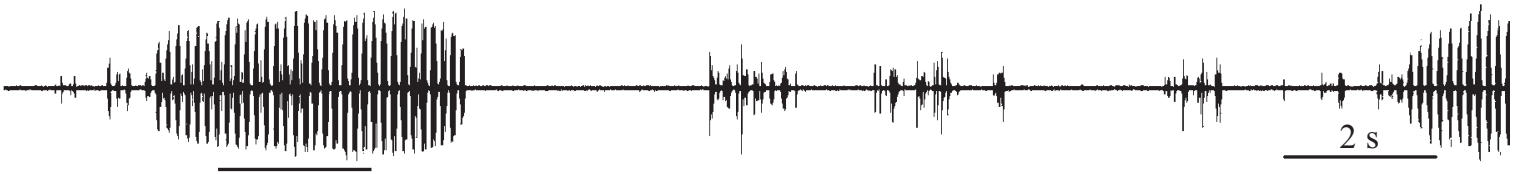

24

25
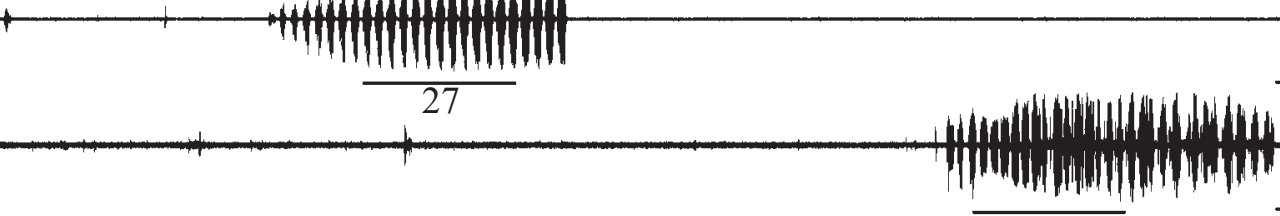

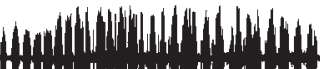
Hon

26

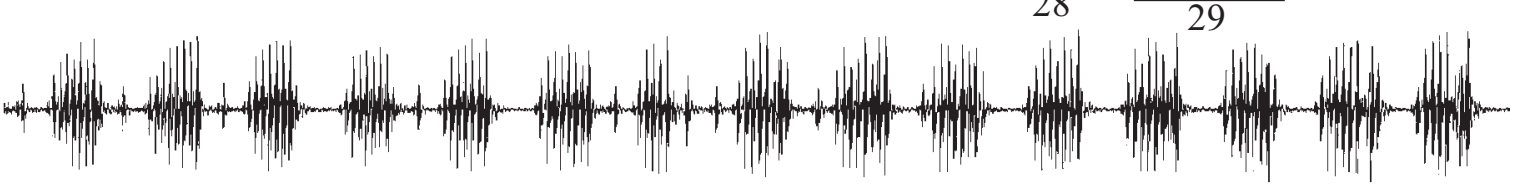

27

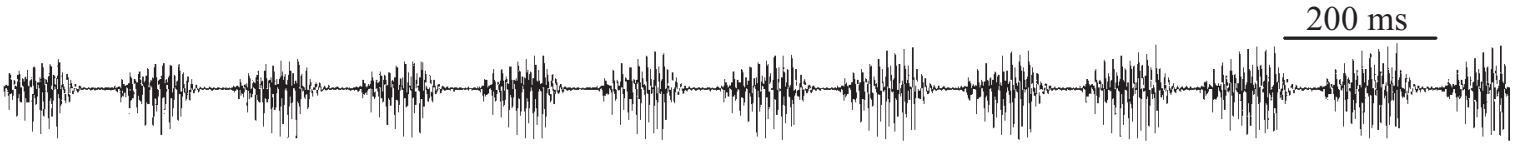

28

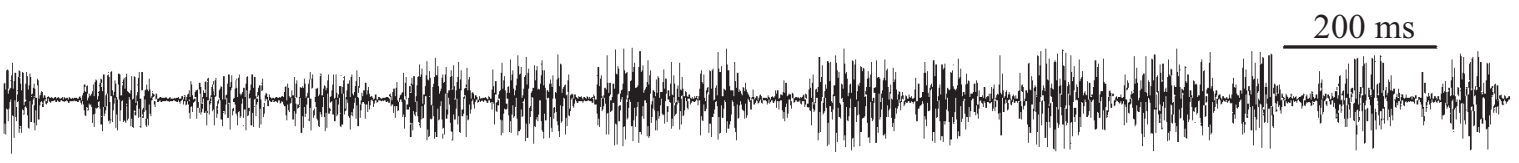

29

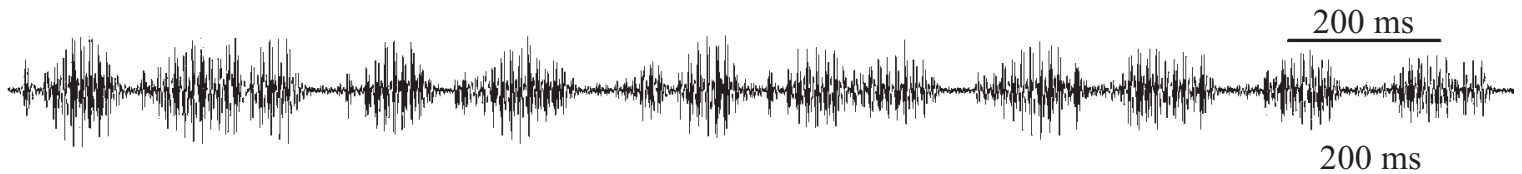

Figs 23-29. Oscillograms of calling signals of Reptalus males: 23-24, 26-27 - R. nigrovenosus (Kusn.); 25, 28-29 - R. narynensis sp.n. Faster oscillograms of the parts of signals indicated as "26-29" are given under the same numbers.

Рис. 23-29. Осциллограммы призывных сигналов самцов Reptalus: 23-24, 26-27 - R. nigrovenosus (Kusn.); 25, 28-29 R. narynensis sp.n. Фрагменты сигналов, помеченные цифрами “26-29”, представлены при большей скорости развертки на осциллограммах под соответствующими номерами.

two species producing calling signals with similar pattern on the same territory is impossible without a partitioning of communication channels. Usually, sympatric species avoid acoustic interference by the time sharing of acoustic activity [e.g. Gogala \& Riede, 1995; Tishechkin, 2010] or due to associations with different plant communities [Tishechkin, 2009]. Apparently, two species of Reptalus demonstrate one more way of communication channels segregation. Both species inhabit similar biotopes in the same range of altitudes, do not differ in phenology and produce calling signals with most similar temporal pattern. On the other hand, during our investigations on Western Tien Shan Mts. they were never found in the same locality. It is as if these two species replace each other in different areas. Since they have similar ecological preferences, it might be assumed that the similarity of their calling song structure is just the reason for such vicariation. Recently similar example of geographic vicariation was described for two closely related Macropsis species (Homoptera: Cicadellidae: Macropsinae) also having identical ecological preferences, producing calling signals with similar pattern and dwelling in the same region of Western Tien Shan Mts. where two Reptalus species discussed above were found [Tishechkin, 2012].

ACKNOWLEDGEMENTS. The second author is greatly indebted to Akynaly Dubanaev (Sary-Cheleksky Biosphere Nature Reserve, Kyrgyzstan) for the support in organisation of investigations in Kyrgyzstan and to Nataliya Burlak (Department of Entomology, Faculty of Biology, M.V. Lomonosov Moscow State University) for invaluable help in the field-work. The study was supported by Russian Foundation for Basic Research, grant No. 10-04-00275-a for D.Yu. Tishechkin.

\section{References}

Gogala M., Riede K. 1995. Time sharing of song activity by cicadas in Temengor forest reserve, Hulu Perak, and in Sabah, Malaysia // Malayan Nature J. Vol.48. P.297-305.

Novikov D.V., Novikova N.V., Anufriev G.A., C.H. Dietrich. 2006. Auchenorrhyncha (Hemiptera) of Kyrgyz grasslands // Russian Entomol. J. Vol.15. No.3. P.303-310.

Tishechkin D.Yu. 2009. Vibrational signals in sympatric species of leafhoppers: Paralimnini (Homoptera: Cicadellidae: Deltocephalinae) in the valley of Irkut River, Eastern Siberia - a case study // Russian Entomol. J. Vol.18. No.4. P.265-272.

Tishechkin D.Yu. 2010. Acoustic signals in the communities of Bryodemini (Orthoptera: Acrididae: Oedipodinae): segregation of communication channels through the temporal divergence of acoustic activity peaks and the emergence of the dusk chorus // Russian Entomol. J. Vol.19. No.4. P.257-265.

Tishechkin D.Yu. 2012. [Taxonomy and biology of the leafhoppers of the genus Macropsis (Homoptera, Cicadellidae, Macropsinae) dwelling on Berberis spp. (Berberidaceae)] // Zoologicheskiy Zhurnal. Vol.91. No.2. P.163-174 [in Russian with English summary]. 